\title{
Survey of wintering Whooper Swans Cygnus cygnus in Sweden in January 2015, and habitat shift in 1995-2015
}

\author{
Inventering av övervintrande sångsvan Cygnus cygnus i Sverige 2015 samt \\ förändring av biotopval 1995-2015
}

LEIF NILSSON

\begin{abstract}
As wintering Whooper Swans Cygnus cygnus have shifted their winter feeding habitats from water to terrestrial ones, the International Waterfowl Counts, covering only coastal and lake sites since its start in 1967, cannot monitor true population change. Therefore, special surveys covering also the terrestrial habitats have been organized in mainland NW Europe every five years since 1995. In January 2015, about 12000 Whooper Swans were recorded in Sweden, an increase from 7400 in 1995. On

the national scale the use of terrestrial habitats shifted from about $30 \%$ in 1995 to about $80 \%$ in 2015 . This shift came first in the southernmost province of Scania where 40\% were feeding in terrestrial habitats already in 1995.

Leif Nilsson, Department of Biology, Biodiversity, Ecology Building, S-223 62 Lund, Sweden E-mail: leif.nilsson.biol.lu.se
\end{abstract}

Received 12 February 2016, Accepted 8 March 2016, Editor: S. Svensson

\section{Introduction}

The Whooper Swan Cygnus cygnus is a widespread wintering waterbird in south Sweden and has been covered by the International Waterbird Counts (IWC) since the start in 1967 (Nilsson 2008, Nilsson \& Haas 2016). During the same period the breeding population of Whooper Swan has increased dramatically in Sweden from a few hundred pairs when the IWC started to a present population estimated to be around 5400 (Nilsson 2014), and it has spread all over the country from a restricted breeding area in northernmost Sweden.

After some time it was clear that the IWC did not reflect the winter population trend in a proper way as the swans were increasingly using terrestrial rather than water habitats for feeding, and only the latter were covered by the IWC (Rose 1995, Nilsson 1997). A special survey, covering terrestrial sites, was started in mainland NW Europe in January 1995 (Laubek et al. 1999, Nilsson 1997). Such surveys have then been repeated every five years with the intention to cover the entire mainland wintering area in northwest Europe. Large scale surveys of the same kind started earlier to cover the British-Icelandic population; (Cranswick et al. 1997).
Here I report the results of the country-wide survey of Whooper Swan in Sweden in January 2015 and evaluate the population development since the previous country-wide survey. Earlier results were presented by Nilsson $(1997,2002,2014)$. The change in utilization of terrestrial habitats is also analyzed.

\section{Material and methods}

Apart from the observations of Whooper Swans made during the annual IWC midwinter counts (cf. Nilsson \& Haas 2016) the following efforts to collect additional data from terrestrial habitats were made. (1) Observers that were taking part in the mid-winter goose counts were asked to check the fields specifically or swans. (2) All local and regional bird clubs were contacted and information was spread via their homepages. (3) As the Whooper Swan is a species that attracts the general public information about the survey was also published in different printed media with both local and national coverage. (4) Information was also given in regional television. 
Table 1. Regional totals of Whooper Swan Cygnus cygnus counted at the special swan counts in 1995-2015. Regionala summor av sångsvan Cygnus cygnus inräknade vid de speciella svanräkningarna 1995-2015.

\begin{tabular}{|c|c|c|c|c|c|}
\hline Län & 1995 & 2000 & 2005 & 2010 & 2015 \\
\hline Skåne & 2303 & 2126 & 2080 & 1534 & 3935 \\
\hline Blekinge & 341 & 454 & 266 & 256 & 903 \\
\hline Jönköpings län & 288 & 177 & 225 & 142 & 212 \\
\hline Kronobergs län & 316 & 312 & 107 & 24 & 153 \\
\hline Kalmar län mainland & 224 & 520 & 729 & 52 & 1184 \\
\hline Öland & 131 & 287 & 96 & 184 & 396 \\
\hline Gotland & 513 & 62 & 600 & 413 & 986 \\
\hline Hallands län & 338 & 319 & 869 & 174 & 387 \\
\hline Bohuslän & 877 & 219 & 491 & 394 & 642 \\
\hline Västergötland & 872 & 1355 & 1620 & 436 & 624 \\
\hline Östergötlands län & 333 & 277 & 226 & 75 & 478 \\
\hline Södermanlands län & 131 & 128 & 262 & 12 & 207 \\
\hline Stockholms län & 150 & 137 & 279 & 177 & 705 \\
\hline Uppsala län & 9 & 0 & 96 & 0 & 15 \\
\hline Västmanlands län & 20 & 40 & 98 & 3 & 1 \\
\hline Örebro län & 73 & 78 & 160 & 25 & 35 \\
\hline Värmlands län & 198 & 378 & 441 & 209 & 462 \\
\hline Kopparbergs län & 199 & 78 & 153 & 63 & 173 \\
\hline Gävleborgs län & 0 & 10 & 3 & 21 & 32 \\
\hline Västernorrlands län & 0 & 9 & 21 & 15 & 23 \\
\hline Jämtlands län & 123 & 56 & 3 & 78 & 72 \\
\hline Västerbottens län & 0 & 0 & 0 & 12 & 3 \\
\hline Norrbottens län & 0 & 0 & 1 & 0 & 0 \\
\hline Total Summa & 7439 & 7022 & 8832 & 4299 & 11648 \\
\hline
\end{tabular}

\section{Result and discussion}

\section{Numbers and distribution}

In January 2015, 11648 Whooper Swans were reported (Table 1, Figure 1). Of these swans only 2054 were reported on the sites covered by the IWC, the others to a large extent found on terrestrial habitats. The swans were widely distributed over southern Sweden north to the river Dalälven, but some small groups were found further north (Table 1). Among the northern counties, Jämtland was found to have more winter swans than the other. These swans were mainly concentrated to the river Indalsälven, where they could find some open and shallow water with vegetation.

During the first special surveys, in 1995 and 2000 , totals of about 7400 respectively 7000 swans were counted. In 2005 and 2015 much higher numbers were found, and the 2015 count of about 12000 swans was 57\% higher than that of 1995 (Figure

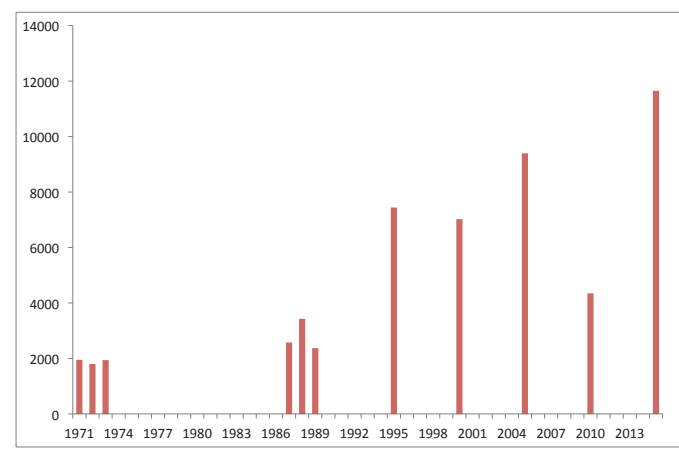

Figure 1. Total number of wintering Whooper Swans Cygnus cygnus in Sweden during earlier country-wide waterbird surveys and the special Whooper Swan counts in 1995, 2000, 2005, 2010 and 2015.

Antalet övervintrande sångsvanar Cygnus cygnus i Sverige vid tidigare landsomfattande sjöfågelinventeringar samt speciella svaninventeringar 1995, 2000, 2005, 2010 och 2015. 

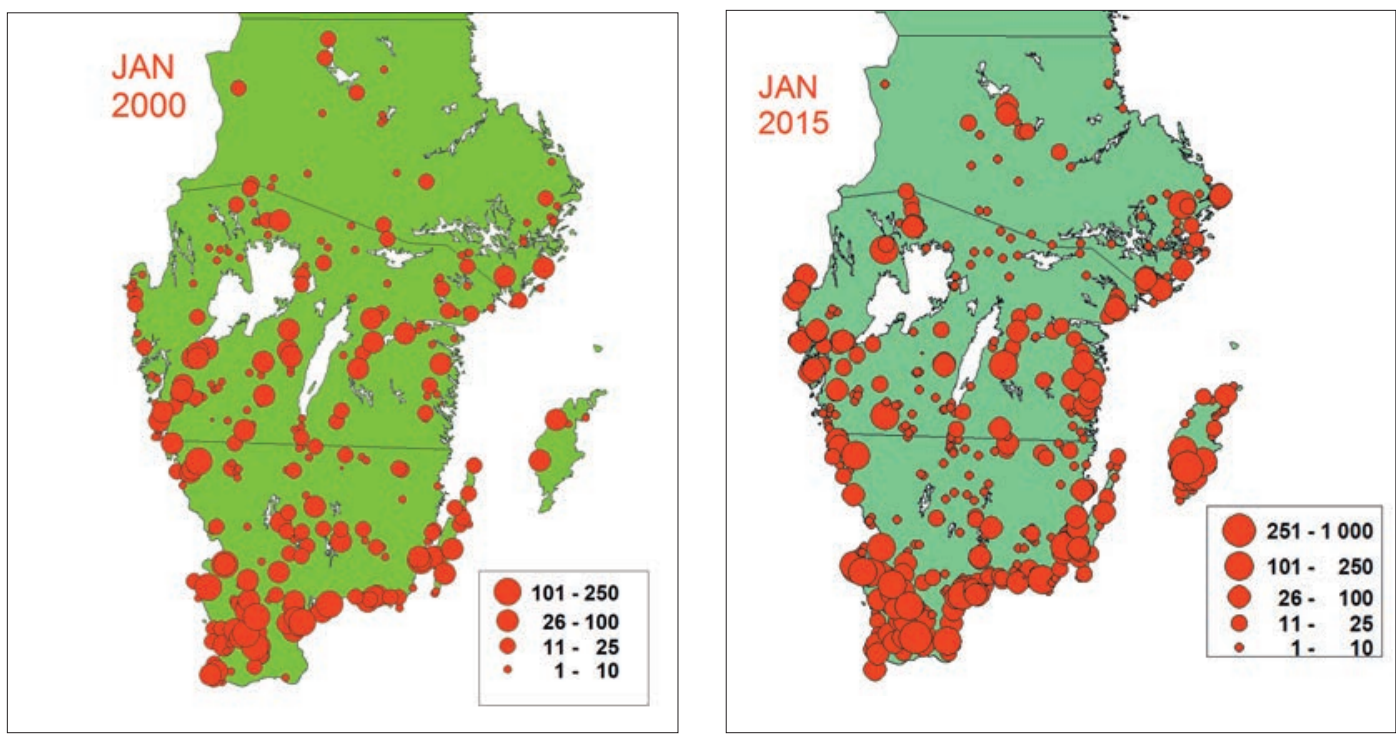

Figure 2. The distribution of wintering Whooper Swans Cygnus cygnus at the special swan surveys in January 2010 and 2015. Utbredningen för övervintrande sångsvanar Cygnus cygnus i Sverige vid de speciella svaninventeringarna $i$ januari 2010 och 2015.

1). During the early seventies, the swans were still mainly concentrated to water habitats and the numbers can therefore be considered to represent the total wintering population. There was only a small increase between 1971-1973 and 1987-1989. The winter of 2010 had much lower numbers than 2005 and 2015 but this was an effect of the severity of that winter.

The general distribution of the wintering Whooper Swans in 2015 was similar to that in1995-2005 (Figure 2) but different from that in January 2010. Apart from much fewer the swans were more concentrated to the coasts, especially to the west and southwest, and to the province of Scania, but the proportion of the national total found in this county was similar in the cold winter of 2010 and the mild winter of 2015.

There was a difference between the southernmost province of Scania and the rest of south Sweden in the speed of shifting from water to terrestrial habitats (Nilsson 1997). During 1995 and 2000 almost all Whooper Swans north of Scania were found on water, whereas this proportion was $40 \%$ in Scania. During the survey in 2015 , a very mild winter, only about $5 \%$ of the Whooper Swans in Scania were counted on water compared to little more than $20 \%$ in Sweden north of Scania. In the northernmost counties the few wintering swans were mostly found on streaming water and at the coast
From the first international swan survey in 1995 , Laubek et al (1999) reported a count of 52000 Whooper Swans in mainland NW Europe and estimated that the total population was in the order of 59 000The Swedish wintering total was about 14\% of the total.

\section{Field Choice}

During the first special Whooper Swan survey $69 \%$ of the swans were still counted on water, both coastal and inland (lakes and streams). This proportion decreased to $42 \%$ in $2000,36 \%$ in 2005 and only $17 \%$ in 2015 . The proportion seen on water is only slightly higher than the percentage of swans counted on the IWC sites.

Over the years there has not only been a change from water habitats to terrestrial habitats among the wintering Whooper Swans, but there have also been changes in the kind of fields used by the swans (Figure 3). During the first three years, winter cereals, grassland and to some extent rape were the important crops used by the swans feeding on terrestrial habitats $(93 \%, 80 \%$, and $62 \%$, respectively). In 2015, grassland was still the most used habitat $(36 \%)$ but fields with spill after the harvest of sugar beet and potatoes had grown much in importance (together 29\%). These two crops were not reported to be used at all during the first three surveys.

Sugar beet and potatoes were not specifically re- 


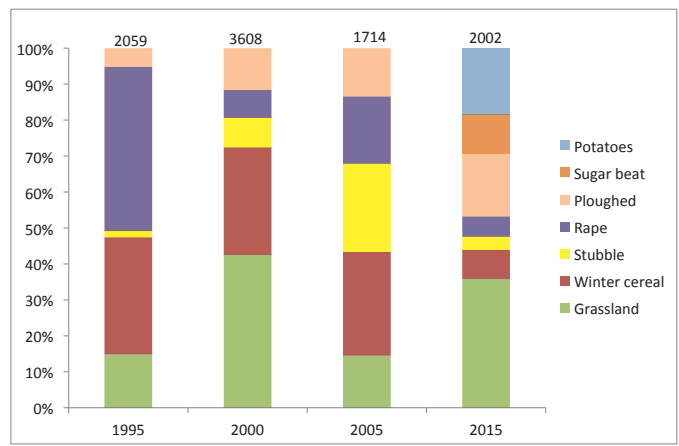

Figure 3. Field choice of wintering Whooper Swans Cygnus cygnus in Sweden counted on terrestrial habitats at the special swan surveys in 1995, 2000, 2005 and 2015. Sample sizes shown above the columns. Note that field choice was not recorded for all swans counted on land.

Fältval hos övervintrande sångsvanar Cygnus cygnus i Sverige räknade på land vid de speciella svaninventeringarna 1995, 2000. 2005 och 2015. Stickprovets storlek visas över staplarna. Observera att fältval inte noterats för alla svanar som räknats på land.

ported during the previous surveys (no data were available from 2010 due to the cold winter with snow-covered fields) but it is highly probable that some of the fields reported as ploughed had been grown by sugar beets. Sugar beet was also a common choice for Whooper Swans on arrival in Scania during the autumn before the ploughing up of the field and appreciable numbers were regularly found on the sugar beet fields during the goose surveys in November. In Scania, the only province with sugar beet in 2015 , close to $40 \%$ of the Whooper Swans were feeding on sugar beet spill.

In the cold and hard winter of 2010, it was not possible to get an accurate sample of the field types used as most terrestrial Whooper Swans were found on snow-covered fields, where they were trying to dig through the snow to get some food. Some unusual feeding habits were seen during this winter (Figure 4). A flock of Whooper Swans together with Greylag Geese Anser anser and Canada Geese Branta canadensis were staying on a harvested field of sugar beet for a longer period during the coldest part of the winter. The farmer had not managed to take in all sugar beet and the remainder was stored under straw to protect it. The Whooper Swans were seen to dig into these frozen heaps of sugar beet and to come out with pieces of beet from deep holes. The geese were also feeding on the sugar beet but were not strong enough to dig and used the holes created by the swans.

From the first international survey data on field choice were also reported (Laubek et al. 1999). A large proportion of the swans were then found on terrestrial habitats in the Netherlands, Germany and Denmark, whereas most swans in Poland and Norway were counted on the water. During this survey, the swans in Scania showed similar habits as the swans further to the southwest, whereas the swans in north o Scania to a large extent used water habitats (Nilsson 1997).

\section{Acknowledgements}

I sincerely thank all people who have answered on the request in media and through the bird clubs but also the duck and goose counters for their reports to the survey without which it could not have been undertaken. The IWC was supported by grants from the Swedish Environmental Protection Agency as a part of the national monitoring program.

\section{References}

Cranswick, P.A., Bowler, J.M., Delany, S.N., Einarsson, O., Gardarsson, A., McElwaine, J.G., Merne, J., Rees, E.C. \& Wells, J.H. 1997. Numbers of Whooper Swans Cygnus cygnus in Iceland, Ireland and Britain in January 1995: results of the international Whooper Swan census. Wildfowl 47: 18-30.

Laubek, B., Nilsson, L., Wieloch, M., Koffijberg, K., Sudfeldt, C. \& Follestad, A. 1999. Distribution, numbers and habitat choice of the NW European Whooper Swan Cygnus cygnus population: results of an international census in January 1995. Vogelwelt 120: 141-154.

Nilsson, L. 1997. Changes in numbers and habitat utilization of wintering Whooper Swans Cygnus cygnus in Sweden 1964-1997. Ornis Svecica 7: 133-142.

Nilsson, L. 2002. Numbers of Mute Swan and Whooper Swans in Sweden, 1967-2000. Waterbirds 25 (Special Publication 1): 53-60.

Nilsson, L. 2008. Changes of numbers and distribution of wintering waterfowl in Sweden during forty years, 19672006. Ornis Svecica 18: 135-226.

Nilsson, L. 2014. Long-term trends in the number of Whoooper Swans Cygnus cygnus breeding and wintering in Sweden. Wildfowl 64: 197-206.

Nilsson, L. \& Haas, F. 2016. Distribution and numbers of wintering waterbirds in Sweden in 2015 and changes during the last fifty years. Ornis Svecica 26:3-54.

Rose, P.M. (ed.). 1995. Western Palearctic and South-West Asia Waterfowl Census 1994. IWRB Publication 35.

\section{Sammanfattning}

Sångsvanbeståndet i Sverige har visat en markant ökning sedan de internationella sjöfågelinventeringarna i landet startade 1967. Under de första åren täckte sjöfågelinventeringarna de övervintrande sångsvanarna på ett bra sätt, men genom åren kom svanarna att ändra vanor och i allt högre grad 

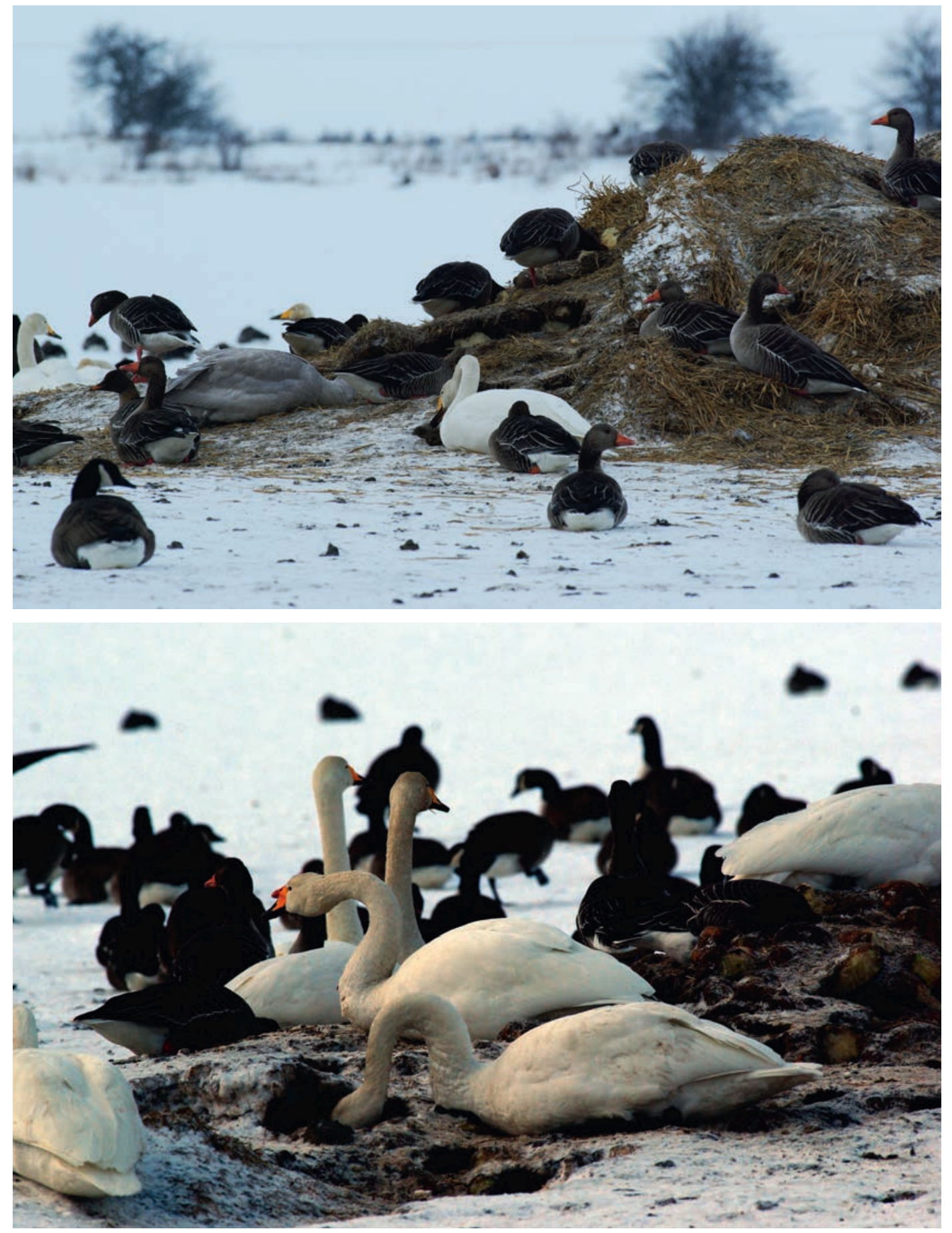

Figure 4. Wintering Whooper Swans Cygnus cygnus feeding on stored sugar beet together with Greylag Geese during the hard winter 2010.

Övervintrande sångsvanar Cygnus cygnus äter av lagrade sockerbetor tillsammans med grågäss under den hårda vintern 2010 
söka föda på fälten inom områden som inte täcks av sjöfågelinventeringarna.

För att bättre täcka in de övervintrande sångsvanarna organiserades därför 1995 en specialinventering av arten i nordvästra Europas fastland (liknande inventeringar hade tidigare genomförts för det bestånd som flyttar mellan Island och de Brittiska öarna). Inventeringarna har sedan upprepats vart 5:e år. I denna uppsats rapporterar jag från inventeringen 2015.

Inventeringen grundas på uppgifter från de pågående gås och sjöfågelräkningarna som kompletterats med ett intensivt sökande efter sångsvanar inom passande områden. Kompletterande information har också insamlats genom kontakter med olika fågelklubbar vartill uppgifter samlats in från allmänheten genom media.

Vid den första specialinventeringen var antalet övervintrande sångsvanar i landet 7400 , medan inre mindre än 11648 räknades in vintern 2015 (Figur 1). Den kalla vintern 2010 sågs dock betydligt färre sångsvanar. Svanarna förekom spridda över hela södra Sverige, men med en koncentration till kusterna och Skåne (Figur 2). Vid de första landsomfattande inventeringarna på 70-talet var antalet sångsvanar under vintern kring 2000.

När de speciella sångsvaninventeringarna startade 1995 fanns fortfarande ca $70 \%$ av sångsvanarna på vatten, en andel som 2015 minskat till mindre än $20 \%$. Fältvalet för de svanar som sökte föda på land har också ändrats genom åren (Figur 3). Vid den senaste milda vintern sökte flera sångsvanar i Skåne föda på skördade betfält, en fält-typ som normalt utnyttjas i betydande utsträckning under hösten innan fälten plöjts. 